\title{
64. ALTERED BASALTS, LEG 37, HOLE 332B
}

\author{
Robert B. Scott, Department of Geology, \\ Texas A \& M University, College Station, Texas
}

Four samples of basalt with evidence of two types of alteration were studied chemically and mineralogically to determine the nature of the alteration. The first type of alteration, found throughout the samples, is recognized by the presence of green smectite in amygdules and in the groundmass. The second consists of iron oxide discoloration along fractures and brecciated zones.

Sample $33-3,22-25 \mathrm{~cm}$ (572.72 to $572.74 \mathrm{~m}$ core depth) contains junctions between an aphyric basalt, a plagioclase-olivine-microglomerophyric glassy basalt, and an amygdaloidal plagioclase-phyric basalt; this complex was then brecciated and filled with calcite. Sample $36-6,4-5 \mathrm{~cm}$ (605.54 to $605.55 \mathrm{~m}$ core depth) is 0.54 meter from the top of a 5.5-meter-thick unit of plagioclase-glomerophyric basalt and Sample 37-2, 72$74 \mathrm{~cm}$ is 0.36 meter from the bottom of the same unit. Sample $42-1,20-22 \mathrm{~cm}$ (655.20 to $655.22 \mathrm{~m}$ core depth) is 0.58 meter from the base of an olivine-phyric basalt unit more than 6.8-meters thick.

Results of chemical studies are shown in Table 1. The aphyric basalt and calcite-free, plagioclase-olivinemicroglomerophyric, glassy basalt of Sample 33-3, 22$25 \mathrm{~cm}$ were analyzed together because they were inseparable. The oxidized margins of Samples 36-6, 4-5 $\mathrm{cm}$ and $37-2,72-74 \mathrm{~cm}$ were selected for analysis. Sample $42-1,20-22 \mathrm{~cm}$ is uniformly oxidized.

Comparison with fresher rocks is difficult because of the highly variable chemistry of basalts from Hole 332B. However, another sample from the same unit as Sample $42-1,20-22 \mathrm{~cm}$ is not described as significantly altered; its composition is $47.5 \% \mathrm{SiO}_{2}, 15.8 \% \mathrm{Al}_{2} \mathrm{O}_{3}$, $10.1 \% \mathrm{Fe}_{2} \mathrm{O}_{3}$ (total), $0.15 \% \mathrm{MnO}, 9.75 \% \mathrm{MgO}, 12.0 \%$ $\mathrm{CaO}, 1.94 \% \mathrm{Na}_{2} \mathrm{O}, 0.07 \% \mathrm{~K}_{2} \mathrm{O}$, and $4.18 \% \mathrm{H}_{2} \mathrm{O}$ (total) (see Chapter 2, this volume). The water content alone indicates that Sample 42-1, 59-61 cm is also altered, but the degree of alteration is less than that for the highly oxidized and veined Sample 42-1, 20-22 cm. If this comparison is valid, it suggests that a greater degree of alteration involves a loss of $\mathrm{SiO}_{2}$ and $\mathrm{MgO}$ and a gain of iron, $\mathrm{K}_{2} \mathrm{O}$, and $\mathrm{CaO}$. Sample 42-1, 20-22 cm has obviously been oxidized, as has Sample $33-3,22-25 \mathrm{~cm}$; both have abundant hematitic coloration and higher iron values than Samples 36-6, 4-5 cm and 37-2, 72-74 $\mathrm{cm}$ without hematitic coloration. These major element trends do not fit those of high-temperature alteration (Hajash, 1974; Mottl et al., 1974; Scott and Hajash, 1975; Bischoff and Dickson, 1975) where $\mathrm{Mg}$ and $\mathrm{Na}$ are lost from the fluid phase and $\mathrm{Ca}, \mathrm{Fe}, \mathrm{Mn}, \mathrm{Si}$, and $\mathrm{K}$ are gained by the fluid phase. The trends do fit the lowtemperature submarine weathering trends (Thompson, 1973) better.
From Haughton et al. (1974) and Scott and Frank (1974), it is clear that significant quantities of S have been lost from the rock; these rocks should have had about $850 \mathrm{ppm}$ originally. $\mathrm{Cu}, \mathrm{Ni}, \mathrm{Cr}, \mathrm{Co}, \mathrm{Hf}$, and $\mathrm{Sc}$ values are close to those typical of oceanic tholeiites (Gast, 1968; Corliss, 1971). The rare-earth-element patterns (Figure 1) appear to be similar to those found in rocks associated with the transition between "normal" depleted ridge basalts and nondepleted plume basalts as those of Iceland and the Afar (Schilling, 1975, 1973a, b, c; Hart et al., 1973). La/Sm ratios of chondrite-normalized values of Hole $332 \mathrm{~B}$ basalts average 0.8 ; this is also typical of the transition between depleted ridge and plume basalt chemistries. However, the $\mathrm{Ce}$ values form a positive anomaly. Probably the oxidizing conditions that created the hematitic coatings along veins also concentrated $\mathrm{Ce}$ in a similar fashion as manganese nodules are enriched in $\mathrm{Ce}$ (Goldberg et al., 1963; Ronov et al., 1967).

A grayish-green clay fills amygdules in Samples 33-6, 4-5 $\mathrm{cm}$ and $37-2,72-74 \mathrm{~cm}$ and appears as a yellow, fibrous clay in thin section (see Sample Descriptions). This clay is found in both oxidized and nonoxidized zones; thus it formed in all the rock prior to local oxidation-type alteration along fractures. From powder camera patterns (Table 2), this clay appears to be the same as that found by Scott and Swanson (1976) in Leg 34 basalts; it is chemically and structurally similar to nontronite (Nagelschmidt, 1938). Isotopic studies of Leg 34 basalts suggest that the altering fluids were close to ambient seawater temperatures (Seyfried et al., 1976; Muehlenbachs, 1974), not higher temperatures as postulated by Scott and Swanson (1976) for pyritenontronitic smectite veins. A similar clay was experimentally grown by reacting seawater with oceanic tholeiite at $400^{\circ}$ and $500^{\circ} \mathrm{C}$ at $0.8 \mathrm{kbar}$ (Hajash, 1974) so the temperature of alteration cannot be uniquely determined by the presence of an iron-rich smectite. Determination of the temperature of fluids that altered Leg 37 rocks will await definitive oxygen isotope studies. In addition to the clay, several amygdules contain analcite and calcite.

Two phases were found in most of the veins. The dominant phase is calcite; no aragonite lines were seen in X-ray powder patterns. However, a Na-zeolite has been tentatively identified in thin section and by X-ray. Small rosettes of a very weakly to nonbirefringent, low index phase with prisms terminated by pyramidal faces has an X-ray powder pattern (Table 3 ) that is very similar to a tetragonal $\mathrm{Na}-\mathrm{P}$ group zeolite, $\mathrm{Na}-\mathrm{Pc}(352)$, synthesized by Taylor and Roy (1964). More 
TABLE 1

Chemical Analyses of Altered Zones, Leg 37, Hole 332B

\begin{tabular}{|c|c|c|c|c|c|}
\hline & $\begin{array}{c}33-3, \\
22-25 \mathrm{~cm} \\
(\%)\end{array}$ & $\begin{array}{c}36-6 \\
4-5 \mathrm{~cm} \\
(\%)\end{array}$ & $\begin{array}{c}37-2, \\
72-74 \mathrm{~cm} \\
(\%)\end{array}$ & $\begin{array}{c}42-1, \\
20-22 \mathrm{~cm} \\
(\%)\end{array}$ & $\begin{array}{l}\text { Precision } \\
(1 \sigma)(\%)\end{array}$ \\
\hline $\mathrm{SiO}_{2}{ }^{\mathrm{a}}$ & 45.8 & 45.2 & 45.7 & 45.6 & \pm 0.5 \\
\hline $\mathrm{Al}_{2} \mathrm{O}_{3}$ & 15.58 & 16.97 & 17.84 & 14.71 & \pm 0.4 \\
\hline $\mathrm{Fe}_{2} \mathrm{O}_{3 \mathrm{~T}}$ & 12.49 & 9.63 & 8.19 & 11.57 & \pm 0.2 \\
\hline $\mathrm{MnO}$ & 0.16 & 0.14 & 0.13 & 0.17 & \pm 0.007 \\
\hline $\mathrm{MgO}$ & 5.78 & 6.83 & 7.86 & 9.28 & \pm 0.01 \\
\hline $\mathrm{CaO}$ & 13.89 & 13.51 & 14.55 & 11.13 & \pm 0.2 \\
\hline $\mathrm{Na}_{2} \mathrm{O}$ & 2.22 & 1.94 & 1.75 & 1.86 & \pm 0.02 \\
\hline $\mathrm{K}_{2} \mathrm{O}$ & 0.141 & 0.230 & 0.114 & 0.120 & \pm 0.001 \\
\hline $\mathrm{H}_{2} \mathrm{O}_{\mathrm{T}}^{\mathrm{b}}$ & $\begin{array}{c}2.59 \\
(\mathrm{ppm})\end{array}$ & $\begin{array}{c}3.90 \\
(\mathrm{ppm})\end{array}$ & $\begin{array}{c}2.34 \\
(\mathrm{ppm})\end{array}$ & $\begin{array}{r}4.19 \\
(\mathrm{ppm})\end{array}$ & $\begin{array}{l} \pm 0.2 \\
(\mathrm{ppm})\end{array}$ \\
\hline$S^{c}$ & 80 & 140 & 40 & 20 & \pm 20 \\
\hline $\mathrm{Cu}$ & 87 & 88 & 92 & 79 & \pm 3 \\
\hline $\mathrm{Ni}$ & 210 & 135 & 155 & 225 & \pm 50 \\
\hline $\mathrm{Cr}^{\mathrm{d}}$ & 405 & 260 & 270 & 525 & \pm 30 \\
\hline $\mathrm{Co}^{\mathrm{d}}$ & 30 & 29 & 33 & 44 & \pm 1 \\
\hline $\mathrm{Sc}^{\mathrm{d}}$ & 42 & 44 & 41 & 42 & $\pm<1$ \\
\hline $\mathrm{Hf}^{\mathrm{d}}$ & 1.5 & 2.2 & 1.8 & 2.3 & \pm 0.1 \\
\hline $\mathrm{La}^{\mathrm{d}}$ & 2.0 & 1.6 & 2.2 & 2.3 & \pm 0.05 \\
\hline $\mathrm{Ce}^{\mathrm{d}}$ & 10 & 13 & 9.4 & 20 & \pm 1.2 \\
\hline $\mathrm{Sm}^{\mathrm{d}}$ & 1.4 & 1.3 & 1.4 & 1.5 & \pm 0.05 \\
\hline $\mathrm{Eu}^{\mathrm{d}}$ & 0.74 & 0.64 & 0.65 & 0.66 & \pm 0.02 \\
\hline $\mathrm{Tb}^{\mathrm{d}}$ & 0.31 & 0.22 & 0.35 & 0.60 & \pm 0.03 \\
\hline $\mathrm{Yb}^{\mathrm{d}}$ & 1.7 & 0.95 & 1.4 & 2.0 & \pm 0.1 \\
\hline $\mathrm{Lu}^{\mathrm{d}}$ & 0.27 & 0.24 & 0.38 & 0.38 & \pm 0.03 \\
\hline
\end{tabular}

Note: Subscript "T" = Total.

${ }^{a}$ By colorimetry.

$\mathrm{b}_{\mathrm{By}}$ gravimetric analy sis.

${ }^{\mathrm{C}}$ By titration.

${ }^{\mathrm{d}} \mathrm{By}$ instrumental activation analysis; rest by atomic absorption spectrophometry.

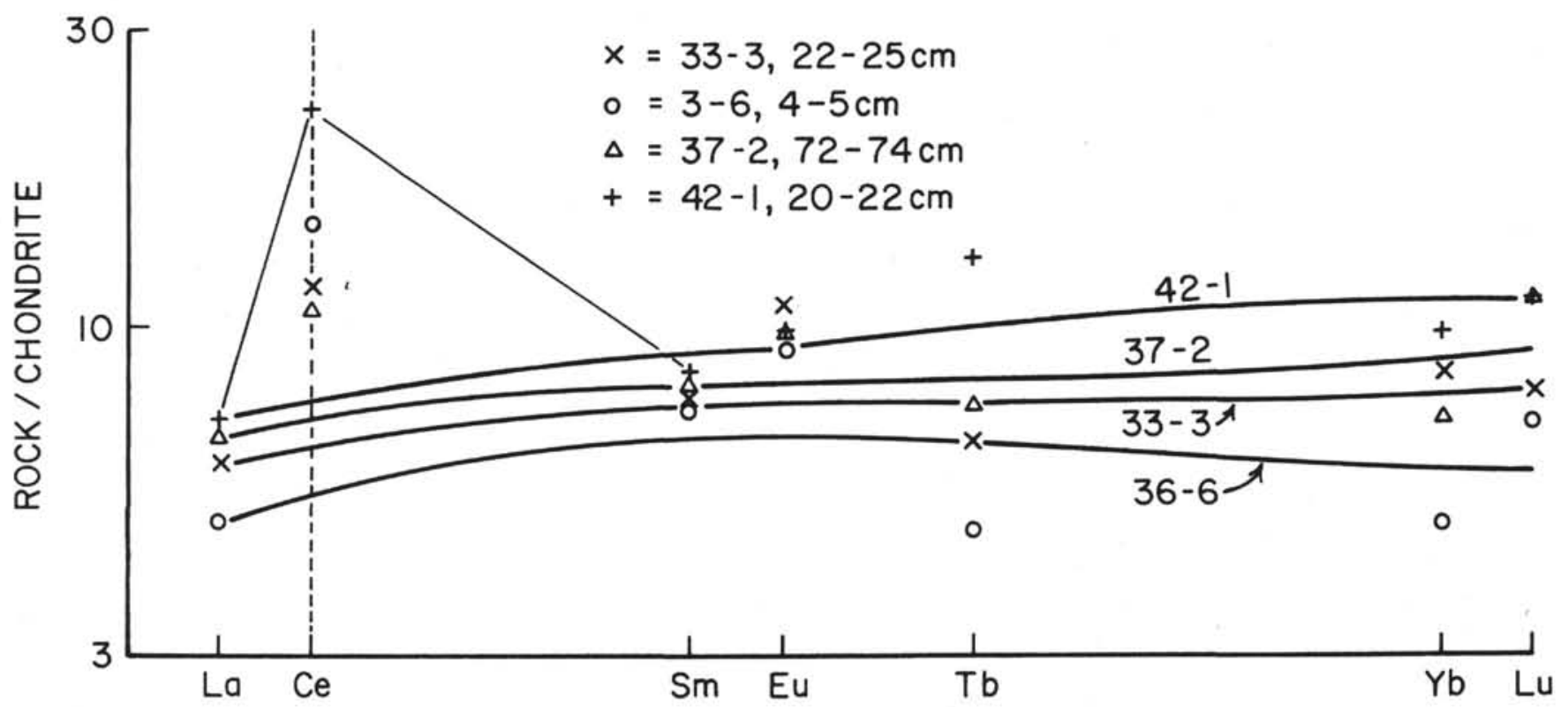

Figure 1. Rare-earth-element abundances normalized to chondritic meteorite abundances. Note positive Ce anomaly. 
TABLE 2

X-Ray Powder Camera Pattern, ${ }^{\mathrm{a}}$ Leg 37, Hole 332B

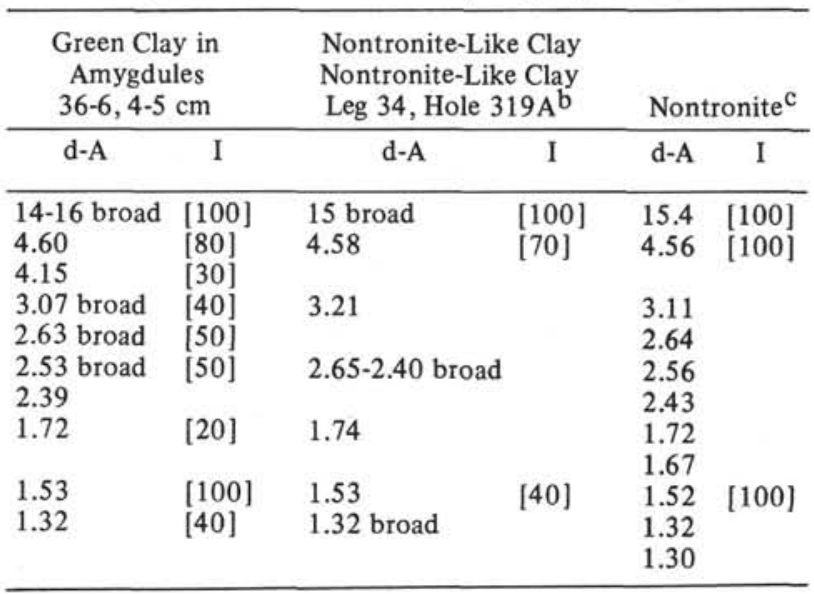

${ }^{\mathrm{a}} \mathrm{Cu}-\mathrm{K} \alpha$ radiation, $\mathrm{Ni}$ filter.

$\mathrm{b}_{\text {Scott }}$ and Swanson (1976)

${ }^{c}$ X-ray analysis of nontronite reported by Nagelschmidt (1938).

mineralogical work seems warranted before positive identification is made.

\section{SAMPLE DESCRIPTIONS}

\section{Sample 33-3, 22-25 cm}

Orientation relative to top unknown, four zones oblique to core axis. Zone 1 is $5 \mathrm{~mm}$ thick. No phenocrysts. Groundmass of $20 \%$ plagioclase (P) + $75 \%$ pyroxene-plagioclase $(\mathrm{Px}-\mathrm{P})$ intergrowths $+5 \%$ opaques (Op). Crystal size decreases sharply at the Zone 1-2 boundary and an oxidized band obliquely crosses the boundary. $5 \%$ amygdules, filled with smectite and calcite. Zone 2 is $7 \mathrm{~mm}$ thick. $10 \%$ microphenocrysts, $60 \% \mathrm{P}+40 \%$ olivine (01). 01 replaced by calcite near Zone 3. Variolitic glassy groundmass with hematitic veinlets is palagonitized near Zone 3. Zone 3 is $18 \mathrm{~mm}$ thick. $50 \%$ brecciated glass in matrix of calcite. Microphenocrysts same as Zone 2 except all 01 replaced by calcite. Borders of zone have less palagonite and more variolites than center. Glass is oxidized and fractures are hematite filled. Zone 4 is $10 \mathrm{~mm}$ thick. Same as Zone 2 except: $1-3 \mathrm{~mm}$ long $\mathrm{P}$ phenocrysts besides microphenocrysts that are $80 \% \mathrm{P}+20 \%$ 01; also larger ( $3 \mathrm{~mm}$ long) irregular calcite amygdules are present.

\section{Sample 36-6, 4-5 cm}

Oxidized near calcite and zeolite veins. Less oxidized zone has 20\% P phenocrysts and one euhedral reddishbrown spinel; groundmass of $\mathrm{P}$ laths $+\mathrm{Px}-\mathrm{P}$ intergrowths $+10 \%$ fibrous, greenish-yellow clay in interstices and replacing 01(?) + fine opaques. Oxidized zone is $6 \mathrm{~mm}$ thick and has abundant hematite. Veins are $1 \mathrm{~mm}$ thick with rosettes of euhedral isotropic zeolite prisms on rims; botryoidal growths of fibrous calcite fill the center.

\section{Sample 37-2, $72-74 \mathrm{~cm}$}

Oxidized near calcite veins. Less oxidized zone has $20 \%$ phenocrysts of $\mathrm{P}+$ greenish-yellow fibrous clay replacing 01 . Slightly ophitic groundmass has $40 \% \mathrm{P}+$ $40 \% \mathrm{Cpx}+3 \% 01(?)$ replaced by clay $+5 \%$ opaques + $5 \%$ clay replacing interstices. $7 \%$ amygdules of calcite + clay + isotropic and anisotropic zeolites. Oxidized zone is $2 \mathrm{~mm}$ thick. Hematite-coated crystal boundaries are abundant. Zeolites in amygdules are common. Veins are $<0.5 \mathrm{~mm}$ thick. Vein sequence: Rock surface | opaque hematite $(0.01 \mathrm{~mm}) \mid$ green, fibrous clay $(0.01$ $\mathrm{mm}) \mid$ hematite $(0.03 \mathrm{~mm}) \mid$ calcite $(0.2 \mathrm{~mm}$ thick $)$.

\section{Sample 42-1, 20-22 cm}

Highly oxidized. $6 \%$ euhedral 01 phenocrysts. Groundmass has P laths + highly oxidized P-Px integrowths. Ubiquitous hematite coats crystal boundaries. $2 \%$ amygdules are filled with calcite + clay + hematite.

TABLE 3

X-Ray Powder Patterns, Leg 37, Hole 332B

\begin{tabular}{|c|c|c|c|}
\hline \multicolumn{2}{|c|}{$\begin{array}{l}\text { Prisms in Veins } \\
\text { of } 36-6,4-5 \mathrm{~cm}\end{array}$} & \multicolumn{2}{|c|}{$\begin{array}{c}\text { Na-Pc (352) } \\
\text { Taylor and Roy } \\
(1964)\end{array}$} \\
\hline d-A & $\mathrm{I}^{\mathrm{a}}$ & d-A & I \\
\hline 7.25 & [50] & 7.10 & [55] \\
\hline 5.40 & [25] & - & \\
\hline 5.03 & [25] & 5.01 & [35] \\
\hline 4.11 & [75] & 4.10 & [55] \\
\hline 3.17 & {$[100]$} & 3.16 & [100] \\
\hline 2.69 & [25] & 2.67 & {$[55]$} \\
\hline \multicolumn{4}{|l|}{ Broad } \\
\hline calcite & overlap & 2.52 & [5] \\
\hline 2.38 & weak & 2.36 & [7] \\
\hline \multicolumn{4}{|l|}{ Broad } \\
\hline calcite & overlap & 2.054 & [5] \\
\hline 1.98 & weak & 1.965 & [10] \\
\hline 1.78 & weak & 1.771 & [7] \\
\hline 1.72 & weak & 1.719 & [7] \\
\hline 1.67 & weak & 1.667 & [7] \\
\hline \multicolumn{4}{|l|}{ Broad } \\
\hline calcite & overlap & 1.623 & [5] \\
\hline
\end{tabular}

${ }^{a}$ Intensity corrected to 100 maximum by ignoring calcite lines. $\mathrm{Cu}$ $\mathrm{K} \alpha$ radiation, $\mathrm{Ni}$ filter.

\section{REFERENCES}

Bischoff, J.L. and Dickson, F.W., 1975. Seawater-basalt interaction at $200^{\circ} \mathrm{C}$ and 500 bars: implications for origin of sea-floor heavy-metal deposits and regulation of seawater chemistry: Earth Planet. Sci. Lett., v. 25, p. 385.

Corliss, J.B., 1971. The origin of metal-bearing submarine hydrothermal solutions: J. Geophys. Res., v. 76, p. 8128.

Gast, P.W., 1968. Trace element fractionation and the origin of tholeiitic and alkaline magma types: Geochim. Cosmochim. Acta, v. 32, p. 1057.

Goldberg, E.D., Koide, M., Schmitt, R.A., and Smith, R.H., 1963. Rare-earth distributions in the marine environment: J. Geophys. Res., v. 68, p. 4209.

Hajash, A., 1974. An experimental investigation of high temperature seawater-basalt interactions: Geol. Soc. Am., Abstracts with Programs, v. 6, p. 771.

Hart, S.R., Schilling, J.G., and Powell, J.L., 1973. Basalts from Iceland and along the Reykjanes ridge: $\mathrm{Sr}$ isotopic geochemistry: Nature Phys. Sci., v. 246, p. 104. 
Haughton, D.R., Roeder, P.L., and Skinner, B.J., 1974. Solubility of sulfur in mafic magmas: Econ. Geol., v. 69, p. 451 .

Muehlenbachs, K., 1974. Oxygen isotope geochemistry of DSDP Leg 34 basalts: Geol. Soc. Am., Abstracts with Programs, v. 6, p. 881 .

Mottl, M.J., Corr, R.F., and Holland, H.D., 1974. Chemical exchange between sea water and mid-ocean ridge basalt during hydrothermal alteration: an experimental study: Geol. Soc. Am. Abstracts with Programs, v. 6, p. 879.

Nagelschmidt, G., 1938. On the atomic arrangement and variability of the members of the montmorillonite group: Min. Mag., v. 25, p. 140.

Ronov, A.B., Balashov, Yu. A., and Migdisov, A.A., 1967. Geochemistry of the rare earths in the sedimentary cycle: Geochem. Internatl., v. 4 , p. 1.

Schilling, J.-G., 1973a. Afar mantle plume: rare earth evidence: Nature Phys. Sci., v. 242, p. 2. p. 141 . 1973b. Iceland mantle plume: Nature, v. 246,

1973c. Iceland mantle plume: geochemical study of Reykjanes ridge: Nature, v. 242, p. 565. , 1975. Rare-earth variations across "normal segments" of the Reykjanes ridge, $60^{\circ}-53^{\circ} \mathrm{N}$, Mid-Atlantic Ridge, $29^{\circ} \mathrm{S}$, and East Pacific Rise, $2^{\circ}-19^{\circ} \mathrm{S}$, and evidence on the composition of the underlying low-velocity layer: J. Geophys. Res., v. 80, p. 1459.

Scott, R.B. and Frank, D.J., 1974. Distribution of sulfur in the ocean crust: Geol. Soc. Am. Abstracts with Program, v. 6, p. 945.

Scott, R.B. and Hajash, A., 1976. Initial submarine alteration of basaltic pillow lavas: a microprobe study: Am. J. Sci., v. 276 , p. 480.

Scott, R.B. and Swanson, S.B., 1976. Mineralogy and chemistry of hydrothermal veins and basaltic host rocks at Sites 319A and 321. In Hart, S. R., Yeats, R.S., et al., Initial Reports of the Deep Sea Drilling Project, Volume 34: Washington (U.S. Government Printing Office), p. 377.

Seyfried, W., Shanks, W., and Bischoff, J.L., 1976. Basalt alteration and vein formation in Site 321 basalts, Leg 34. In Hart, S.R., Yeats, R.S., et al., Initial Reports of the Deep Sea Drilling Project, Volume 34: Washington (U.S. Government Printing Office), p. 385.

Taylor, A.M. and Roy, R., 1964. Zeolite studies IV: Na-P zeolites and the ion-exchanged derivatives of tetragonal Na-P: Am. Mineral., v. 49, p. 656.

Thompson, G., 1973. A geochemical study of the low temperature interaction of sea-water and oceanic igneous rocks: EOS Trans. Am. Geophys. Union, v. 54, p. 1015. 